\title{
Abstracts
}

\author{
Romantics, Stoics, and Martyrs in Seventeenth-Century China
}

Frederic Wakeman, JR. Pages 631-665

The rigors of the transition from Ming to Qing imposed harrowing moral choices upon Chinese elites during the 1600 s. Some chose to collaborate uneasily with their Manchu conquerors. Others remained loyal to the Ming, even after all hope was lost for a restoration in the South. Yet a third group transferred its support from the fallen dynasty to the rising one, becoming so fiercely attached to the new rulers that its members were willing to endure martyrdom rather than turn against the Manchus during the Rebellion of the Three Feudatories. Although such choices were often situational and not always mutually exclusive, they were associated in contemporaries' eyes with distinct aesthetic tastes, specific philosophical positions, and particular political commitments. This essay attempts to identify those distinctions in the biographical trajectories of several eminent seventeenth-century literati, scholarofficials, and military statesmen.

\section{Individualism in Taishō Japan}

\section{Sharon Hamilton Nolte Pages 667-684}

The author identifies three meanings of individualism (kojinshugi) in Japanese journalism during the Taishō period. They were: first, individual character and talent should be cultivated for the purpose of strengthening the state and fostering the active commitment of individuals to state policies; second, personal autonomy and selfexpression were legitimate within a restricted "private" sphere that coexisted uneasily with the dominant values of the "public" sphere; and third, the development of free, autonomous individuals was the most fundamental value by which state and society should be judged. Proponents of individualism were unable to alter the state structure established by the Meiji Constitution or the state ideology of submission; their innovative thinking did serve as a leavening agent within state structure by demanding new relationships between elite and masses and by sustaining a high degree of elite pluralism.

\section{Korea's First Newspaper: The Japanese Chösen shinpō}

\section{Albert A. Altman Pages 685-696}

In 1881 , the Japanese introduced the newspaper as a means of public communication into Korea. Publication of the Chosen shinpō in the open port of Pusan is related to the political and economic circumstances in which the Japanese found themselves 
there. Elsewhere in East Asia, a comparable role was played by Westerners. In addition to viewing the Cbōsen shinpō in the context of Japanese efforts to influence Korea's modernization, the author suggests studying this newspaper as a component of the comparative history of the press in East Asia.

\section{Ritual Paradoxes in Nepal: Comparative Perspectives on Tamang Religion \\ David Holmberg Pages 697-722}

Every religious system in Nepal, including that of the Tamang, is multifaceted and has numerous practitioners. Without apparent contradiction, western Tamang simultaneously engage Buddhist lamas who preside over elaborate rites of death, sacrificial lambu who propitiate chthonic divinities and exorcise harmful agents, and shamanic bombo who recapture lost shadow souls, revive life-force, unveil an enigmatic divine, and reveal. Interpretations of religion in Nepal have treated divergent ritual strands as isolates, and there is a persistent image of the religious situation in Nepal as an amalgam of Hindu, Buddhist, and indigenous strands. This article, which ends with a Tamang myth about diverse ritual strands, concludes that particular ritual practices must be interpreted with reference to their relations to other strands in an encompassing ritual field. The field, though, need not be coherent and unified, as has often been assumed in culture theory. The ritual structure of the Tamang emerges as a variant of other ritual systems found throughout Nepal and in greater South and Southeast Asia.

\section{The Paleoenvironment of North China-A Review Article}

PING-T1 Ho Pages $723-733$

K. C. Chang has been instrumental in the West in propagating the view that North China in Neolithic times was lush, moist, and densely forested. A close scrutiny of data relating to palynology, soil science, and paleoclimate, however, indicates that the true loess areas of North China were, and have always been, semiarid steppe. In addition, the author considers Chang's belief that the earliest northern Chinese agriculture was a system of slash-and-burn or shifting cultivation to be invalid. Whereas the crucial problem in the slash-and-burn systems of the tropics and humid areas is fertility, the crucial problem in the agriculture of the loess areas is moisture, not fertility. The ability of loess soil to retain its fertility under semiarid conditions has accounted for the self-sustaining character of the agriculture of North China. These important issues, and others, are discussed in the volume under review. 